\title{
THE RELATION BETWEEN THE SERUM UREA CONCENTRATION AND THE PROTEIN CONSUMPTION OF NORMAL INDIVIDUALS ${ }^{1}$
}

\author{
BY T. ADDIS, E. BARRETT, L. J. POO, AND D. W. YUEN \\ (From the Department of Medicine, Stanford University School of Medicine, \\ San Francisco, California)
}

(Received for publication January 28, 1947)

When a patient with renal disease is found to have a concentration of urea in his blood that is higher than usual we would like to be able to derive from the degree of increase in concentration some idea as to the degree of decrease in the urea-excreting function of his kidneys. In the individual patient this cannot safely be done. True, when we plot the blood urea concentrations of a large number of patients against their urea clearances, a general relation does emerge $(1,2)$. However, in any one of such a group of patients the prediction from concentration to clearance may fall dangerously far from the truth. This is inevitable because the concentration of urea in the body is determined not only by how much urea runs out of the system through the kidneys but also by how much urea runs into it from the liver. When more runs out than runs in, the concentration falls to a lower level which is maintained as long as the discrepancy persists. When more runs in than runs out the concentration level rises and remains high as long as the excess of in-flow over out-flow continues. Unlike salt, the concentration of urea is confined within no narrow zone of variation by any regulatory mechanism. Urea is a substance to which the body is chemically and physically indifferent. It is an end product of protein metabolism and participates in no chemical reactions. Except in the kidney it has no osmotic effect because it is distributed evenly through the water of all organs and tissues. So we need not be surprised when we find, as we do, that there is a wide scatter in the urea concentrations in the blood of normal individuals $(3,4)$. In spite of wholly normal renal function we shall continue to find this high variability until we make measurements on normal subjects who are taking the same amounts of protein in their food; and in our patients, whose

1 This work was made possible by a grant from the Nutrition Foundation, Inc. renal function is not normal, we shall not be able to derive reliable judgments as to the renal significance of our blood urea determinations until we know their food protein consumption and can exclude any pronounced deviation from the usual rate of endogenous protein catabolism.

When an acutely ill patient first reaches a hospital it is generally recognized that even a quite high blood urea concentration cannot be taken as conclusive evidence of renal failure. There is always the chance that this may be an example of "extra-renal azotemia," a term used to cover any sudden and pronounced increase in urea formation by the liver, whether the amino acids from which it is derived come from the gastrointestinal tract, as in massive blood loss into the gut, or from a rapid breakdown of the protein of the body itself, as in certain patients with obstruction of the small intestine. The conditions that lead to such explosive disintegrations of large amounts of protein are not often found in ambulatory patients. In them, we may suppose, differences in the rate of urea formation arise mainly from differences in the quantities of protein they take as food. It is for this group, and particularly for out-patients with renal disease, that we might get more information from blood urea measurements if only we were able to discount this protein consumption variable. That cannot be done until we measure the effect of variation in protein consumption on the blood urea concentration of normal individuals. ${ }^{2}$

2 In accordance with clinical usage we speak of blood urea concentrations although the determinations were actually carried out on plasma or serum. When whole blood is used the urea concentration is found to be about 1 per cent less than in serum because the red cells contain less water than the serum. This is true only when the arginase in the red cells has been destroyed by heat, before the urease is added. Otherwise determinations on whole blood give a variable plus error which we believe arises because the arginase in the red cells produces urea from arginine in the urease (5). 
The data given in this paper were collected with that end in view.

\section{Method}

\section{The conditions under which the observations were made}

The experiment was made possible through the intelligent and devoted cooperation of 2 groups of people: first, the 10 medical students who were the subjects, and, second, the student dietitians who designed and prepared weighed diets containing varying quantities of protein. The effect of 3 levels of protein consumption was studied. The first contained an amount of protein not much more than is required for nitrogen equilibrium (6). This was obtained by giving each subject 0.5 gram of protein for every kilogram of his body weight (with clothes). The second represented a medium protein consumption and provided 1.5 grams of protein per $\mathrm{kgm}$. The third, a high protein diet, supplied 2.5 grams of protein for every $\mathrm{kgm}$. of body weight. The subject who weighed $80 \mathrm{kgm}$. thus received, first, 40 grams, then 120 grams, and, finally 200 grams of protein a day. ${ }^{3}$ The calories in all cases exceeded 2,000 a day. There was no restriction of water. The subjects continued with their daily work. Blood was collected on the 5 th and 6 th days of the consumption of each level of protein. On the 5th day the first blood was taken at 7:15 a.m. before breakfast at 7:30 a.m., then at $11: 45$ a.m. before lunch at 12 noon, at $4: 45$ p.m. before dinner at 5 p.m., and at 9:45 p.m. before going to bed at 10 p.m. On the 6 th day observations were made at 7:15 a.m. and at 11:45 a.m. just before breakfast and lunch. Between each diet there was a period during which whatever food the subjects wanted was taken. The 0.5gram level was taken first, then the 1.5, and then the 2.5gram level. After a 2-month interval the 0.5- and the 2.5 -gram diets were repeated. We thus obtained 120 serum urea determinations on 0.5 gram, 60 on 1.5 grams and 108 on 2.5 grams, a total of 288 observations.

\section{The method of measurement}

A urease-aeration-titration method was used (7). In spite of constant care and reiterated checking with known urea solutions we suspect that our data may be marred by the occasional intrusion of unsuspected technical errors. We have reason also to think that there is a constant minus eror of nearly 3 per cent arising from unavoidable loss in the transfer of ammonia. In spite of these imper-

${ }^{3}$ The body weights of our subjects varied from 65 to 83 kilograms. Unquestionably somewhat more precise results would have been obtained if we had apportioned the protein in terms of some power of the body weight. The method we used is based on the not quite correct supposition that there is a relation of direct proportionality between body weight and protein requirement. We used it because this is the simple first approximation that we and many others employ in day-to-day clinical work. fections we believe the method adequate for our purpose. That this is so is indicated, though not proved, by the general agreement between our present results and the results we obtained with the same method in 1940 . In these earlier measurements the subjects were different (10 residents and internes) but the protein variation was the same. Unfortunately, in 1940, blood was taken only once a day, so that the comparison has to be restricted to the measurements made at 11:45 a.m. on the 5th day of each diet in 1941 and the measurements made at the same time of the 5th day in the present series. The degree of agreement is shown in Table I.

We cannot say how much of the divergence between the 2 sets of observations shown in Table I should be ascribed to inconsistency in the technique of measurement. It is enough to observe that the sum of the technical and of all other reasons for difference do not prevent us from

TABLE I

Comparison of blood urea concentrations measured at 11:45 a.m. in 1940 with concentrations measured at 11:45 a.m. in the present series using the same method

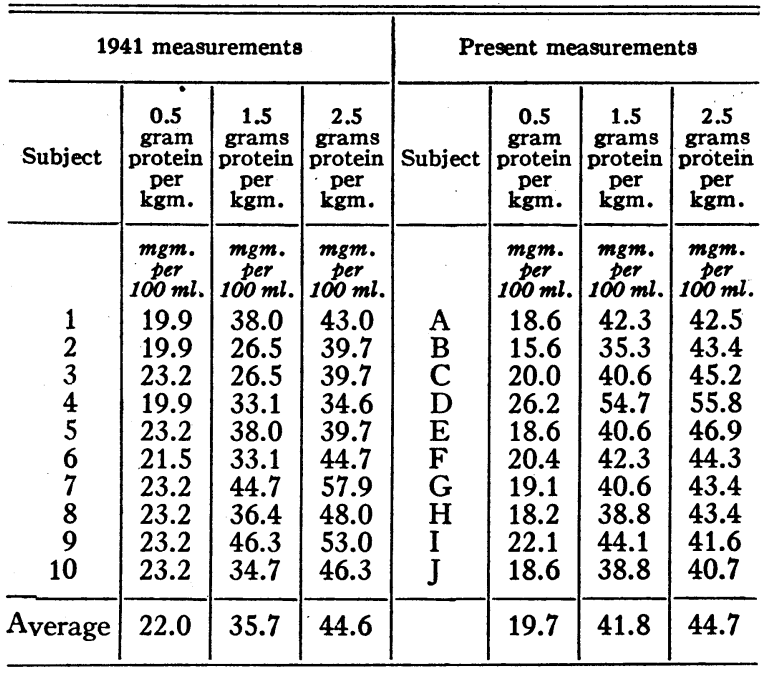

TABLE II

Individual averages from observations made at all times of day on varying levels of protein concentration

\begin{tabular}{c|c|c|c|c}
\hline \hline Subject & $\begin{array}{c}\text { 0.5 gram } \\
\text { protein } \\
\text { per kgm. }\end{array}$ & $\begin{array}{c}1.5 \text { grams } \\
\text { protein } \\
\text { per kgm. }\end{array}$ & $\begin{array}{c}2.5 \text { grams } \\
\text { protein } \\
\text { per kgm. }\end{array}$ & $\begin{array}{c}\text { Individual } \\
\text { averages for } \\
\text { the 3 } \\
\text { diets }\end{array}$ \\
\cline { 2 - 4 } J & $\begin{array}{c}\text { mgm. per } \\
100 \text { ml. }\end{array}$ & $\begin{array}{c}\text { mgm. per } \\
100 \text { ml. }\end{array}$ & $\begin{array}{c}\text { mgm. per } \\
100 \text { ml. }\end{array}$ & $\begin{array}{c}\text { mgm. per } \\
100 \text { ml. }\end{array}$ \\
B & 18.3 & 37.8 & 40.9 & 32.3 \\
H & 17.6 & 39.3 & 40.4 & 32.4 \\
A & 17.8 & 34.9 & 45.2 & 32.6 \\
F & 17.9 & 36.9 & 44.4 & 33.1 \\
G & 19.1 & 36.9 & 43.5 & 33.2 \\
C & 19.8 & 36.6 & 44.2 & 33.6 \\
I & 18.9 & 35.8 & 47.6 & 34.1 \\
E & 18.3 & 40.5 & 43.0 & 34.6 \\
D & 24.4 & 39.6 & 49.2 & 35.8 \\
\hline
\end{tabular}




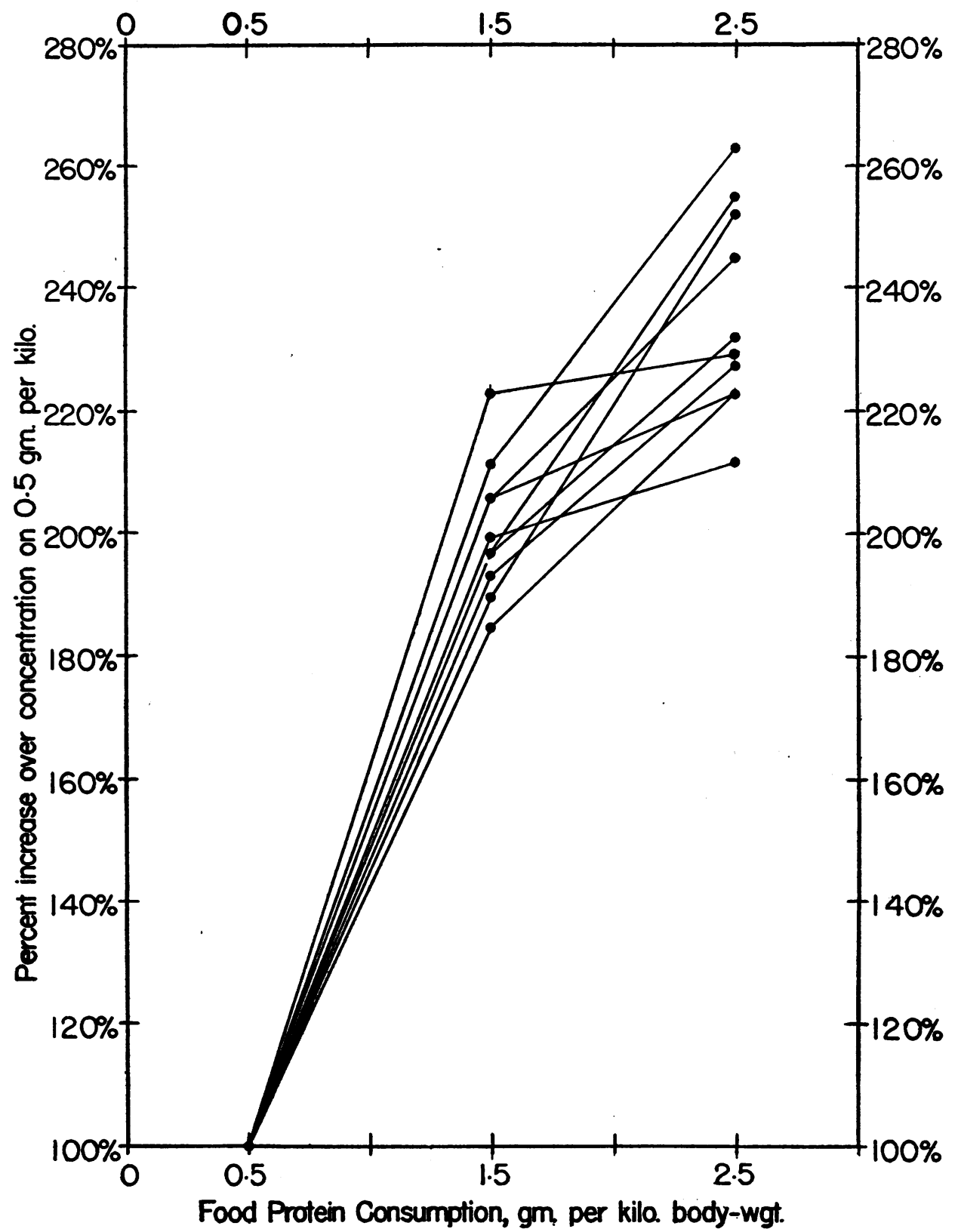

Fig. 1. The Relation between the Serum Urea Concentration and the Protein CONSUMPTION OF NORMal Individuals

concluding that in both of these groups of normal subjects the blood urea concentration rises as the protein consumption increases and is more than twice as high on the 2.5 as on the 0.5 gram of protein per kilogram diet.

\section{The individual variability of the subjects}

There are indications of individual peculiarities in the 20 subjects dealt with in Table I, but no conclusion can be drawn from these fluctuations because the number of observations on each subject is too small. We can get a better idea as to how much one individual may differ from another in his reaction to increase in protein consumption from the present series of observations. For each subject we have 12 measurements on 0.5 gram, 6 on 1.5 grams, and 11 or 10 on 2.5 grams of protein per kilogram. The averages for each individual are given in Table II and the percentage increases above the concentration on the 0.5 -gram level are shown in graph form for each of the 10 subjects in Figure 1. 
Though every subject has an increase in concentration with increase in protein, these results reveal considerable individual differences. It does not seem to us, however, that the question as to the probability that these differences arise from factors constant for each subject is one that our data can answer with sufficient dependability to give a result of practical value. For the moment it is enough to note that, if we take the concentration observed in each subject on the 0.5 -gram protein diet as 100 per cent, these normal individuals responded to the 1.5-gram protein diet by increases in concentration that varied from 185 per cent to 223 per cent and from 212 per cent to 263 per cent when 2.5 grams of protein per $\mathbf{k g m}$. was taken.

For clinical purposes it is most important to know how great is the individual variation in concentration in normal subjects taking the same amount of protein. This question is answered in the last column of Table II where we give the averages of 29 observations on 8 subjects, and 28 on the other 2 , at all times of day and under all diets. The subjects have been arranged in the order of magnitude of their averages.

In 9 subjects there is a close concordance in blood urea concentration, with a range of from 32.3 to $35.8 \mathrm{mgm}$. per $100 \mathrm{ml}$. The subject $\mathrm{D}$, however, has an average of 43.1 mgm. per $100 \mathrm{ml}$. Yet he was what we call "normal," that is, he considered his health good, he was working hard, and, in particular, was free from any sign of renal disease. There was nothing unusual in his reaction to increase in food protein, for it happens he falls close to the center of the stream of variation shown in Figure 1. It is fortunate that we happened to include this subject, for if some other student, who was like the rest of the group, had taken his place, the reported variability in blood urea concentration would have been narrowed. It is obvious that measurements of normality based on 10 subjects have only a preliminary and tentative significance.

\section{RESULTS}

We neglect all variables except the change in protein consumption and present only the averages and their standard deviations on $0.5,1.5$ and 2.5 grams of protein per kgm. body weight. This means that we include the variability arising from the fact that the blood samples were taken at various times during the two 24-hour cycles within the variation induced by the protein. We prefer to merge these 2 distinguishable effects because we intend to use our measurements for the interpretation of the urea concentration of patients no matter at what time of day we take their blood.

In Table III we give the averages and their standard deviations. In Figure 2, the averages are plotted against the protein consumption and the area lying between the averages plus or minus twice the standard deviations is indicated. This
TABLE III

Averages and variabilities of blood urea concentrations on varying and on all levels of protein consumption

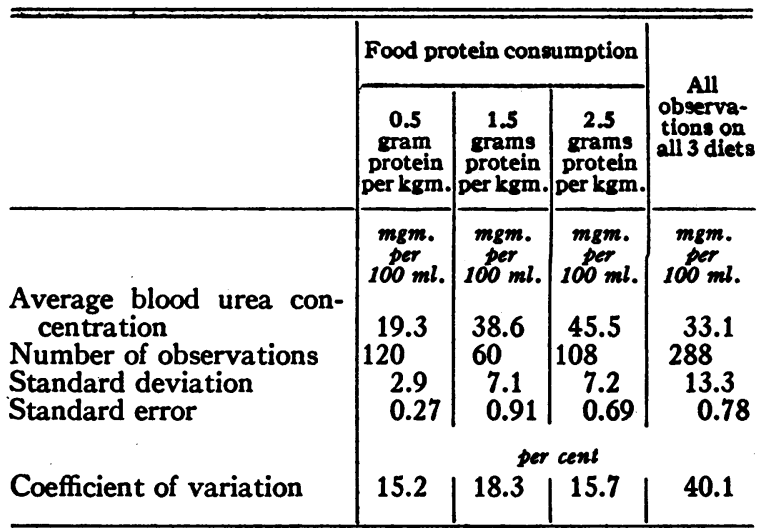

area is delimited by lines because we want to use it for the interpretation, from blood urea concentration measurements, of the renal status of patients who are taking any quantity of protein between 0.5 and 2.5 grams per $\mathrm{kgm}$. The lines are broken in order to indicate that when the protein consumption is other than 1 of the 3 quantities at which our measurements were made we are dealing with assumed and not with measured variabilities.

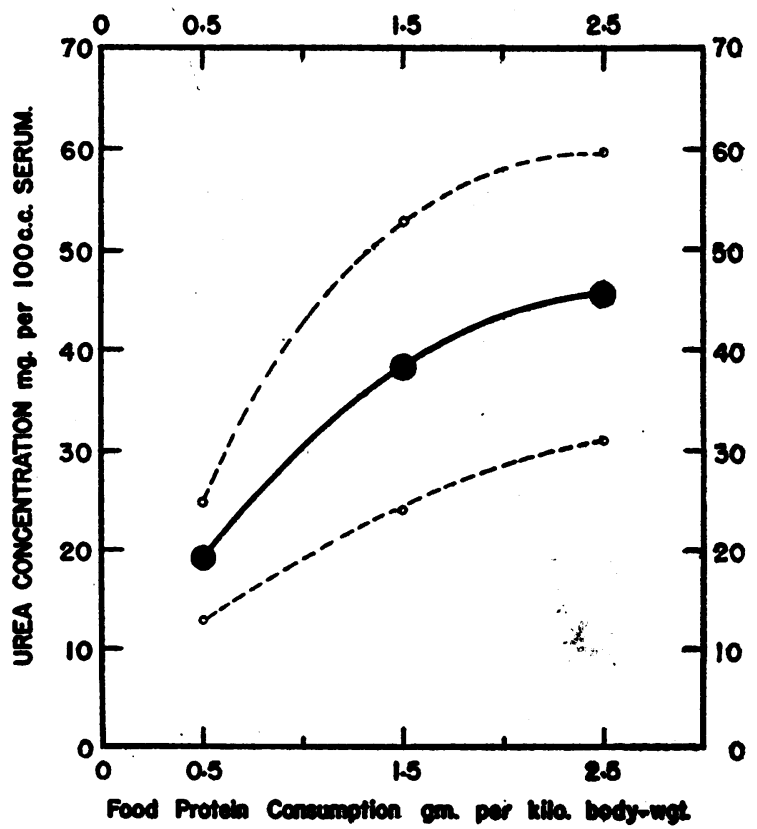

Fig. 2. The Relation between the Serum Urea Concentration and the Protein Consumption of NORMAL IDTVIDUALS 


\section{DISCUSSION}

The average of all the 288 measurements is 33 mgm. Of these 95 per cent lie between $7 \mathrm{mgm}$. and $60 \mathrm{mgm}$. of urea per $100 \mathrm{ml}$. of blood. This result is in conformity with what has already been observed $(4,5)$. All it does is to demonstrate, more precisely than before, how wide is the variability in the concentration of urea in the blood of apparently healthy young adults who present no evidence of any defect in renal function. If this were all, we should have to conclude that, even for ambulatory patients with renal disease, a measurement of blood urea concentration was of little value, apart from its use in revealing the more extreme degrees of renal failure.

Now, however, the effect of variation in protein consumption has been measured in normal individuals. As we go from 0.5 to 1.5 to 2.5 grams of protein per $\mathrm{kgm}$. their blood urea concentration rises from 19 to 39 to $45 \mathrm{mgm}$. per $100 \mathrm{ml}$. At each of these levels of protein consumption the variability is much lower than the 40 per cent coefficient of variation that characterizes the whole series. It is reduced to 15 per cent at 0.5 gram, 18 per cent at 1.5 grams, and 16 per cent at 2.5 grams. This means that we now have measurements on which we can base our clinical judgments with greater assurance.

The prerequisite for the use of these standards is a knowledge of the quantity of protein the patient takes. But this is what is already known by everyone who believes that the protein consumption of a patient with renal disease is an important factor in his treatment. Many of our patients are living on self-measured diets that contain 0.5 gram of protein per $\mathrm{kgm}$. We have reason to know that these measurements have a reasonable precision. That is a matter that can be verified by periodic determinations of their rate of urea excretion. If, in such a patient, we find a blood urea concentration of $40 \mathrm{mgm}$. per $100 \mathrm{ml}$. we can be almost certain that he has a urea clearance well below normal. We know that because in Figure 1 we see that on 0.5 gram of protein per $\mathrm{kgm}$. only about 2 per cent of people with unimpaired renal function have urea concentrations that exceed 25 mgm. per $100 \mathrm{ml}$. If, as the months and years go by, while the same diet is maintained, we find this patient's concentration rising from 40 to 50 to
$60 \mathrm{mgm}$., or falling from 40 to 30 to $20 \mathrm{mgm}$., we now have some warrant for the supposition that his urea clearance has changed in an approximately proportionate inverse manner.

Whatever average quantity of protein a patient loses in his urine is added to his diet. In some this may amount to 10 , in others to 15 and in still others to 20 grams of protein a day. Thus the protein taken by an $80-\mathrm{kgm}$. patient may be increased from 40 , to 50 , to 55 or to 60 grams of protein a day, that is from 0.5 to 0.63 , to 0.69 , to 0.75 gram of protein per $\mathrm{kgm}$. In such patients there are reasons, and some of them are more than statistical, why we cannot have the same assurance in the interpretation of urea concentrations measured at levels of protein consumption other than those at which our determinations were made. Until we have more extensive information, however, our best guess is to assume smooth curves between the measured points in Figure 1. Then, if a patient is taking 0.75 gram of protein per kgm., we shall be guided in the estimation of the urea-excreting function of his kidney by the supposition that, with unimpaired function, the average concentration would be $25 \mathrm{mgm}$. and that in only 2 per cent of all such instances would the concentration be more than $33 \mathrm{mgm}$. per $100 \mathrm{ml}$.

In theory, we can now predict the urea clearance of any ambulatory patient whose protein consumption is known. In practice, however, we have to remember that 10 medical students are not an adequate sample of all people whose renal function is supposedly intact. More than that, the theory involves the assumption that the rate and variability of "endogenous" protein catabolism in patients with renal disease is similar to that which existed in our normal sample. That is a supposition that has never been tested. Nevertheless we find these normal standards useful, even though we are aware that our "predictions" are not much more than clinical judgments, influenced in an indeterminate manner by considerations arising from a concrete knowledge of the particular circumstances that surround each one of our patients.

\section{CONCLUSIONS}

1. The average of 288 determinations of the urea concentration in the blood of 10 medical students was $33 \mathrm{mgm}$. per $100 \mathrm{ml}$. The range of variation 
that included 95 per cent of the measurements went from 7 to $60 \mathrm{mgm}$. of urea per $100 \mathrm{ml}$.

2. When the subjects took 0.5 gram of food protein per $\mathrm{kgm}$. body weight the average of $120 \mathrm{blood}$ urea concentration determinations was $19 \mathrm{mgm}$. per $100 \mathrm{ml}$., and 95 per cent lay between 13 and 25 mgm. per $100 \mathrm{ml}$. On a diet containing 1.5 grams of protein per $\mathrm{kgm}$. the average of 60 determinations was 39 mgm., and 95 per cent fell between 25 and $53 \mathrm{mgm}$. per $100 \mathrm{ml}$. When 2.5 grams of protein per kgm. was taken, the average of 108 determinations was $45 \mathrm{mgm}$. and the same proportion was included in a range from 31 to $60 \mathrm{mgm}$. per $100 \mathrm{ml}$.

\section{BIBLIOGRAPHY}

1. MacKay, E. M., and MacKay, L. L., The relation between the blood urea concentration and the amount of functioning renal tissue. J. Clin. Invest., 1927, $4,127$.

2. Van Slyke, D. D., McIntosh, J. F., Möller, E., Hannon, R. R., and Johnson, C., Studies of urea excretion. VI. Comparison of the blood urea clearance with certain other measures of renal function. J. Clin. Invest., 1930, 8, 357.

3. Addis, T., and Watanabe, C. K., The causes of variation in the concentration of urea in the blood of healthy adults. Arch, Int. Med., 1917, 19, 507.

4. MacKay, E. M., and MacKay, L. L., The concentration of urea in the blood of normal individuals. J. Clin. Invest., 1927, 4, 295.

5. Addis, T., An error in the urease method for the determination of urea. Proc. Soc. Exper. Biol. \& Med., 1928, 25, 365.

6. Hegsted, D. M., Tsongas, A. G., Abbott, D. B., and Stare, F. G., Pratein requirements of adults. J. Lab. \& Clin. Med., 1946, 31, 261.

7. Addis, T., Urea determinations in blood and urine. J. Lab. \& Clin. Med., 1925, 10, 402. 